OPEN ACCESS

Edited by:

Airton Kunz,

Embrapa Suínos e Aves, Brazil

Reviewed by:

Eduardo Moreno Jiménez,

Universidad Autonoma de Madrid,

Spain

Gislaine Fongaro,

Universidade Federal da Fronteira Sul,

Brazil

*Correspondence:

Mingxin Guo

mguo@desu.edu

Specialty section:

This article was submitted to

Waste Management in

Agroecosystems,

a section of the journal

Frontiers in Sustainable Food Systems

Received: 14 March 2018

Accepted: 11 May 2018

Published: 30 May 2018

Citation:

Li W, Feng $X$, Song $W$ and Guo $M$ (2018) Transformation of Phosphorus in Speciation and Bioavailability During Converting Poultry Litter to Biochar Front. Sustain. Food Syst. 2:20 doi: 10.3389/fsufs. 2018.00020

\section{Transformation of Phosphorus in Speciation and Bioavailability During Converting Poultry Litter to Biochar}

\author{
Wei $\mathrm{Li}^{1}$, Xionghan Feng ${ }^{2}$, Weiping Song ${ }^{3}$ and Mingxin Guo ${ }^{4 *}$ \\ ${ }^{1}$ Key Laboratory of Surficial Geochemistry, Ministry of Education, School of Earth Sciences and Engineering, Nanjing \\ University, Nanjing, China, ${ }^{2}$ Key Laboratory of Arable Land Conservation (Middle and Lower Reaches of Yangtze River), \\ Ministry of Agriculture, College of Resources and Environment, Huazhong Agricultural University, Wuhan, China, \\ ${ }^{3}$ Department of Chemistry, Delaware State University, Dover, DE, United States, ${ }^{4}$ Department of Agriculture and Natural \\ Resources, Delaware State University, Dover, DE, United States
}

Converting poultry litter (PL) to biochar and applying the biochar to cropland as a soil amendment may be a best approach for recovering nutrients from solid biowastes while minimizing nutrient runoff losses from the treated field. To evaluate the potential of PL-derived biochar as a slow-release phosphorus $(P)$ fertilizer, the speciation, lability, and bioavailability of $\mathrm{P}$ in $\mathrm{PL}$ and the derived biochars were examined and compared. Raw PL and its derived biochars through $300-600^{\circ} \mathrm{C}$ slow pyrolysis were analyzed for total $\mathrm{P}(\mathrm{TP})$, inorganic $\mathrm{P}(\mathrm{IP})$, and organic $\mathrm{P}(\mathrm{OP})$ contents. The TP was fractionated into readily, generally, moderately, low, and non-labile pools by sequential extraction with different solutions. The TP was further assessed for bioavailability using batch extraction by water, Olsen, Bray-1, Mehlich-3, and $1 \mathrm{M} \mathrm{HCl}$ extractants. The P species in biochars were characterized using solid-state ${ }^{31} \mathrm{P}$ nuclear magnetic resonance (NMR) techniques. The results indicate that during pyrolysis $\mathrm{OP}$ in PL was transformed to IP and water-soluble $\mathrm{P}$ to low labile forms such as hydroxyapatite and oxyapatite especially at higher temperature. Bray-1 and Mehlich-3 were appropriate extractants for evaluating the immediate to medium-term available and the long-term available $\mathrm{P}$ in biochar, respectively. Converting $\mathrm{PL}$ to biochar through $\leq 450^{\circ} \mathrm{C}$ pyrolysis significantly reduced the water-soluble proportion and the lability of $\mathrm{P}$ but did not compromise the long-term $\mathrm{P}$ bioavailability, resulting in a P-enriched, slow release soil amendment that would minimize the $\mathrm{P}$ runoff risks following field application. The promising results need to be further validated in soil-biochar-plant systems.

Keywords: poultry litter biochar, phosphorus speciation, hydroxyapatite, lability, chemical extraction

\section{INTRODUCTION}

Poultry production (domestic fowl rearing for meat and eggs) is a crucial economic activity in nearly all countries to furnish affordable diet protein and suppress hunger. Intensive and concentrated bird rearing, however, generates vast volumes of litter waste (mixture of feces, sheddings, and bedding materials) that requires appropriate disposal (Bolan et al., 2010). The U.S. poultry industry, for example, generates annually more than 550 million dry tons of litter waste (Coker, 2017). Poultry litter (PL) contains high contents of organic carbon (OC, $\sim 380 \mathrm{~g} \mathrm{~kg}^{-1}$ ) and the plant nutrients nitrogen $\left(\mathrm{N}, \sim 40 \mathrm{~g} \mathrm{~kg}^{-1}\right)$, phosphorus $\left(\mathrm{P}, \sim 15 \mathrm{~g} \mathrm{~kg}^{-1}\right)$, and potassium 
( $\mathrm{K}, \sim 38 \mathrm{~g} \mathrm{~kg}^{-1}$ ) (Guo et al., 2009a) and is predominantly disposed of through land application as an organic fertilizer. The P:N ratio (e.g., 1:2-1:3) of PL is much higher than the typical crop nutrient requirement (e.g., 1:6-1:8) (Sadras, 2005) and therefore, application of PL at N-based agronomic rates would result in over-fertilization of $\mathrm{P}$, which is subject to runoff losses to natural water bodies. In regions with concentrated poultry production, repeated and excess application of PL to cropland has introduced substantial loads of $\mathrm{P}$ and $\mathrm{N}$ nutrients to local water systems, causing eutrophication, and general water quality degradation issues (NASA, 2016). Phosphorus exists in PL principally in labile forms (e.g., water-soluble, $0.5 \mathrm{M}$ $\mathrm{NaHCO}_{3}$-extractable, and organic P) (Dou et al., 2000; Li et al., 2014). Up to $50 \%$ of the P in PL is water extractable (Dou et al., 2000) and can be rapidly released into the soil water via rainfall following land application (Guo et al., 2009b). To reduce the risks of $\mathrm{P}$ runoff from land-applied PL, it is critical to decrease the $\mathrm{P}$ water extractability and release rate of the organic fertilizer.

Biochar is a promising soil amendment capable of persistently enhancing soil quality through ameliorating soil physical, chemical, and biological properties (Guo et al., 2016). Converting agricultural byproducts and other organic residues to biochar and utilizing the biochar as a soil amendment may be a best management practice for recovering nutrients and sustaining soil quality. Research demonstrates the feasibility of manufacturing nutrients-enriched biochar by pyrolysis of PL for promoting crop growth (Chan et al., 2008; Revell et al., 2012; MierzwaHersztek et al., 2016). Depending on the pyrolysis conditions especially the temperature and time duration, the yield of biochar ranged from 45 to 60 mass\% of the feedstock PL (Song and Guo, 2012). Nearly $100 \%$ of the PL-P was recovered in biochar (Song and Guo, 2012). Pyrolysis significantly transformed the $\mathrm{P}$ in $\mathrm{PL}$ and reduced the water extractable portion of $\mathrm{P}$ from $19.5 \%$ of total $\mathrm{P}$ in raw $\mathrm{PL}$ to $<7.0 \%$ in biochar. As the pyrolysis temperature was elevated from 300 to $600^{\circ} \mathrm{C}$, the portion of $0.01 \mathrm{M} \mathrm{HCl}$-extractable $\mathrm{P}$ in the PL-derived biochar products decreased from $>55 \%$ of total $\mathrm{P}$ to $<16 \%$ (Song and Guo, 2012). Pyrolysis at $400^{\circ} \mathrm{C}$ converted the labile $\mathrm{P}$ in raw $\mathrm{PL}$ to $\mathrm{Mg} / \mathrm{Ca}$ phosphate minerals in biochar and reduced the water-soluble $\mathrm{P}$ from $2.95 \mathrm{~g} \mathrm{~kg}^{-1}$ in raw PL to $0.17 \mathrm{~g} \mathrm{~kg}^{-1}$ in biochar (Wang et al., 2015). In PL biochar, orthophosphate was predominant while organic phosphate (a major form of P in raw PL) was barely present. Furthermore, release of P from PL biochar in water and neutral soils was significantly slower and steadier than from raw PL (Wang et al., 2015). Relative to raw PL, the derived biochar is a slow P release fertilizer (Dai et al., 2016). To date the transformation processes of $\mathrm{P}$ in PL during pyrolysis have not been fully understood. The existing forms of $\mathrm{P}$ in PL-derived biochar are not clear, and the bioavailability of the biochar P lacks assessment. The objective of this study was to examine the transformation of $\mathrm{P}$ in speciation and bioavailability during converting PL to biochar under varying pyrolysis conditions, aiming to optimize the pyrolysis operation for producing a slow release yet efficiently available $\mathrm{P}$ soil amendment from animal wastes.

\section{MATERIALS AND METHODS}

\section{Poultry Litter}

Poultry litter was procured from an industrial facility in Seaford, DE that processes raw PL collected from local broiler farms into a marketable fertilizer product via a series of physical and mechanical operations. The PL predominantly in $<4 \mathrm{~mm}$ granules contained $92.3 \mathrm{wt} \%$ of dry matter and $7.7 \mathrm{wt} \%$ of moisture. The dry matter was comprised of $71.5 \mathrm{wt} \%$ organic constituents and $28.5 \mathrm{wt} \%$ ash minerals. On the dry mass basis the PL contained total N 30.7 , total P 13.7 , and total $\mathrm{K} 41.8 \mathrm{~g} \mathrm{~kg}^{-1}$. More nutrient composition information of the PL can be found in Table 1 of Song and Guo (2012). The PL was used as received.

\section{Converting PL to Biochar}

The PL was converted to biochar through slow pyrolysis at varied peak temperatures, with duplicate trials performed at each selected temperature. Briefly, $650 \mathrm{~g}$ of the granular PL were weighed into a metal canister $(11 \mathrm{~cm}$ i.d. $\times 13 \mathrm{~cm}$ height $)$ to its volume at loose packing. The canister was covered by its metal lid that had a 5-mm hole in the center. The canister was placed in an Isotemp muffle furnace (Thermo Fisher Scientific, Inc., Suwanee, GA) and heated at a pre-determined temperature $\left(300-600^{\circ} \mathrm{C}\right)$ until the pyrolysis was complete, as indicated by no further visible smokes escaping from the furnace. The furnace was able to raise its internal temperature at $20^{\circ} \mathrm{C} / \mathrm{min}$ and maintain a pre-set constant temperature with continuous power supply. Pyrolysis of PL inside the canister started when the furnace temperature reached above $250^{\circ} \mathrm{C}$, signified by visible smokes (pyrolysis vapors) emitted out of the $4-\mathrm{cm}$ gas vent in the top panel of the furnace. It took 130-370 min for the pyrolysis of PL in the canister to be complete, the time shortened as the peak pyrolysis temperature increased in the range of $300-600^{\circ} \mathrm{C}$.

Once the complete pyrolysis was achieved, the furnace was switched off, and the canister was taken out and cooled to the room temperature with immediate sealing of the lid hole with a piece of metal tape. The biochar in the canister was then transferred into a Ziploc plastic bag and stored in a dark cabinet at $22^{\circ} \mathrm{C}$ prior to further characterization. More details of the biochar preparation methods can be found in Song and Guo (2012). The peak temperatures $300,350,400,450,500,550$, and $600^{\circ} \mathrm{C}$ were used to produce biochars from PL through pyrolysis operations varying in temperature, the most important parameter that controls the yield and quality of biochar derived from a specific feedstock (Guo et al., 2012). The PL-derived biochar samples are hereafter referred to as C300, C350, C400, C450, C500, C550, and C600, respectively.

\section{Chemical Characterization of $P$ in PL and Biochar Samples}

The PL and the derived biochars were ground to $<0.15 \mathrm{~mm}$ and stored in brown glass vials. Total P (TP) and its constituents inorganic P (IP) and organic P (OP) of the samples were analyzed. The contents of TP were determined by acid digestion and colorimetric P measurement (Song and Guo, 2012). For each sample, duplicate measurements were conducted. All the laboratory wares were of glass or Teflon and were acid-washed. 
TABLE 1 | Contents of total phosphorus (TP) and its inorganic phosphorus (IP) and organic phosphorus (OP) fractions in poultry litter (PL) and the derived biochars.

\begin{tabular}{|c|c|c|c|c|c|}
\hline & $\begin{array}{c}\text { TP } \\
\mathrm{g} \mathrm{kg}^{-1}\end{array}$ & \multicolumn{2}{|c|}{ IP } & \multicolumn{2}{|c|}{ OP } \\
\hline PL & $13.70 \pm 0.90$ & $9.26 \pm 0.026$ & $67.62 \pm 1.77^{\mathrm{a}}$ & $4.44 \pm 0.93$ & $32.38 \pm 1.77^{\mathrm{a}}$ \\
\hline С300 & $22.73 \pm 0.15$ & $19.78 \pm 0.12$ & $87.03 \pm 0.18^{b}$ & $2.95 \pm 0.27$ & $12.97 \pm 0.18^{b}$ \\
\hline C350 & $24.02 \pm 0.086$ & $23.01 \pm 0.12$ & $95.79 \pm 0.13^{d}$ & $1.01 \pm 0.21$ & $4.21 \pm 0.13^{d}$ \\
\hline C400 & $26.29 \pm 0.42$ & $25.58 \pm 0.048$ & $97.31 \pm 0.31^{e}$ & $0.71 \pm 0.47$ & $2.69 \pm 0.31^{e}$ \\
\hline C550 & $29.84 \pm 0.52$ & $27.04 \pm 0.024$ & $90.63 \pm 0.32^{\mathrm{C}}$ & $2.80 \pm 0.54$ & $9.37 \pm 0.32^{\mathrm{C}}$ \\
\hline $\mathrm{C} 600$ & $30.54 \pm 0.86$ & $27.25 \pm 0.024$ & $89.23 \pm 0.51^{c}$ & $3.29 \pm 0.88$ & $10.77 \pm 0.51^{c}$ \\
\hline
\end{tabular}

Data are means \pm standard deviations of duplicate measurements. Superscript letters denote significance of difference between treatment levels.

In operation, $0.20 \mathrm{~g}$ of a sample were transferred into a $45-\mathrm{mL}$ Teflon digestion cylinder (Parr Instrument Company, Moline, IL), followed by addition of $5.0 \mathrm{~mL}$ Milli-Q water and $5.0 \mathrm{~mL}$ concentrated $\mathrm{HNO}_{3}$. Procedure blanks without sample addition were included. After gentle swirling for mixing, the cylinder was capped and placed into a digestion case and microwaved at 0.6 KW for $2.5 \mathrm{~min}$. The digestion bomb was left in the microwave oven to cool to nearly room temperature, then opened, and the digestate in the cylinder was fully transferred into a $100-\mathrm{mL}$ volumetric flask with several times of Milli-Q water rinsing. The digestate in the flask was brought to $100 \mathrm{~mL}$ by adding Milli-Q water, well-mixed, and passed through a $0.45-\mu \mathrm{m}$ glass fiber filter to remove any particulates. The clear digestate was then analyzed for TP concentrations using the standard phosphomolybdate blue method (Murphy and Riley, 1962). The IP contents were determined by extracting the samples with $1 \mathrm{M} \mathrm{HCl}$ at 1:50 solid/solution ratio under room temperature rotary shaking for $24 \mathrm{~h}$, centrifuging the extract at 4,080 $\times \mathrm{g}$ for $20 \mathrm{~min}$., passing the supernatant through a $0.2-\mu \mathrm{m}$ syringe filter, and measuring the $\mathrm{P}$ content of the filtered extract using the phosphomolybdate blue method (de Jonge et al., 1993). The OP contents were computed as the difference between TP and IP of a sample. The method detection limit was $3.0 \mathrm{mg} \mathrm{kg}^{-1}$.

To examine the fractionation of $\mathrm{TP}$ in different pools showing distinct leachability and bioavailability, the PL and biochar samples in duplicates were sequentially extracted by Milli-Q water, $0.5 \mathrm{M} \mathrm{NaHCO}_{3}, 0.1 \mathrm{M} \mathrm{NaOH}$, and $1 \mathrm{M} \mathrm{HCl}$, each at 1:50 solid/solution ratio (Qian and Jiang, 2014). At each sequential extraction step, the solid/solution slurry was continuously agitated by $30 \mathrm{rpm}$ rotary shaking at room temperature for $24 \mathrm{~h}$ and centrifuged at $4080 \times \mathrm{g}$ for $20 \mathrm{~min}$ to separate the mixture into supernatant and pellet. The supernatant was passed through a $0.2-\mu \mathrm{m}$ syringe filter and collected in a $50-\mathrm{mL}$ volumetric flask; the pellet was washed twice each by $10 \mathrm{~mL}$ Milli-Q water and the rinsate was combined with the supernatant. The next sequential extraction step was then started by adding a new extractant solution and re-suspending the pellet. Any $\mathrm{P}$ remaining in the pellet after the sequential $1 \mathrm{M} \mathrm{HCl}$ extraction was treated as residual $\mathrm{P}$ (non-labile, non-bioavailable) of the original sample. The extract in the volumetric flask was brought to volume with Milli-Q water and analyzed for concentrations of total dissolved $\mathrm{P}\left(\mathrm{P}_{\mathrm{t}}\right)$, dissolved organic $\mathrm{P}\left(\mathrm{P}_{\mathrm{o}}\right)$, dissolved inorganic $\mathrm{P}\left(\mathrm{P}_{\mathrm{i}}\right)$, dissolved inorganic orthophosphate $\mathrm{P}\left(\mathrm{P}_{\mathrm{r}}\right)$, and dissolved inorganic polyphosphate $\mathrm{P}\left(\mathrm{P}_{\mathrm{X}}\right)$. Prior to bringing to the volume, the $\mathrm{NaHCO}_{3}-$ and $\mathrm{NaOH}$-extracts were adjusted to $\mathrm{pH}$ just below 8 by drop-adding concentrated $\mathrm{HCl}$ with phenolphthalein as the indicator. The $\mathrm{P}_{t}, \mathrm{P}_{\mathrm{i}}$, and $\mathrm{P}_{\mathrm{r}}$ concentrations of the sequential extracts were measured following the phosphomolybdate blue method after acidic $\mathrm{K}_{2} \mathrm{~S}_{2} \mathrm{O}_{8}$ autoclave digestion, $\mathrm{H}_{2} \mathrm{SO}_{4}$ autoclave digestion, and no pretreatment of the extracts, respectively (Wang et al., 2015). Once again, procedure blanks without sample addition were included. All standard P solutions for establishing the calibration curves were subject to the same digestion processes as the extracts. The method detection limit was $0.91 \mathrm{mg} \mathrm{kg}^{-1}$. The $\mathrm{P}_{\mathrm{O}}$ was computed as the difference between $\mathrm{P}_{t}$ and $\mathrm{P}_{\mathrm{i}}\left(\mathrm{P}_{\mathrm{O}}=\mathrm{P}_{\mathrm{t}}\right.$ - $\left.\mathrm{P}_{\mathrm{i}}\right)$ and $\mathrm{P}_{\mathrm{x}}$ as the difference between $\mathrm{P}_{\mathrm{i}}$ and $\mathrm{P}_{\mathrm{r}}\left(\mathrm{P}_{\mathrm{x}}=\mathrm{P}_{\mathrm{i}}-\right.$ $\mathrm{P}_{\mathrm{r}}$ ). For the $\mathrm{HCl}$-extracts, only $\mathrm{P}_{\mathrm{r}}$ was measured; no organic $\mathrm{P}$ or inorganic polyphosphate $\mathrm{P}$ was expected in this extract and therefore, $\mathrm{P}_{\mathrm{r}}=\mathrm{P}_{\mathrm{i}}=\mathrm{P}_{\mathrm{t}}$ was assumed (Qian and Jiang, 2014).

To further estimate the bioavailability of $\mathrm{P}$ in the PL and biochar samples, the fractions of Mehlich-3 P, Bray-1 P, and Olsen $\mathrm{P}$ were measured by batch extraction methods (Pierzynski, 2000). Briefly, 0.5-g aliquots of the samples were extracted separately by $25 \mathrm{~mL}$ of Mehlich-3 extractant $\left(0.2 \mathrm{M} \mathrm{CH}_{3} \mathrm{COOH}\right.$ $+0.015 \mathrm{M} \mathrm{NH}_{4} \mathrm{~F}+0.013 \mathrm{M} \mathrm{HNO}_{3}+0.001 \mathrm{M} \mathrm{EDTA}+0.25 \mathrm{M}$ $\left.\mathrm{NH}_{4} \mathrm{NO}_{3}\right)$, Bray-1 extractant $\left(0.025 \mathrm{M} \mathrm{HCl}\right.$ in $\left.0.03 \mathrm{M} \mathrm{NH}_{4} \mathrm{~F}\right)$, and Olsen extractant $\left(0.5 \mathrm{M} \mathrm{NaHCO}_{3}, \mathrm{pH}\right.$ adjusted to 8.5$)$ at room temperature for $24 \mathrm{~h}$ under continuous rotary shaking and the extracts were analyzed for $\mathrm{P}_{\mathrm{t}}$ concentrations following the phosphomolybdate blue method after acidic $\mathrm{K}_{2} \mathrm{~S}_{2} \mathrm{O}_{8}$ autoclave digestion. For each sample, duplicate measurements were conducted. Procedure blanks without sample addition were included. The method detection limit was $0.61 \mathrm{mg} \mathrm{kg}^{-1}$.

\section{Spectroscopic Characterization of $\mathbf{P}$ in PL-Derived Biochar Samples}

To identify the existing species of $\mathrm{P}$ in PL-derived biochar, solidstate ${ }^{31} \mathrm{P}$ single-pulse (SP) and ${ }^{31} \mathrm{P}\left\{{ }^{1} \mathrm{H}\right\}$ cross-polarization (CP) magic-angle spinning (MAS) nuclear magnetic resonance (NMR) spectra of the biochar samples were collected on a $400 \mathrm{MHz}$ Varian Unity Inova spectrometer (Varian, Inc., Palo Alto, CA) at 
operating frequencies of 161.8 and $399.8 \mathrm{MHz}$ for ${ }^{31} \mathrm{P}$ and ${ }^{1} \mathrm{H}$, respectively. Spectra were collected using a Varian/Chemagnetics T3-type probe, with samples contained in $7.5 \mathrm{~mm}$ (o.d.) normal wall $\mathrm{ZrO}_{2}$ rotors. The ${ }^{31} \mathrm{P}\left\{{ }^{1} \mathrm{H}\right\} \mathrm{CP} / \mathrm{MAS}$ spectra were obtained at the spinning rate of $5 \mathrm{kHz}$ with $\mathrm{CP}$ contact time of $1 \mathrm{~ms}$ using the same probe. The CP kinetic curves were measured at a spinning rate of $5 \mathrm{kHz}$ with contact times varying from 0.3 to $5 \mathrm{~ms}$ and irradiation under the $n=-1$ sideband match condition. For all $\mathrm{CP} / \mathrm{MAS}$ spectra, the transverse ${ }^{1} \mathrm{H}$ field $\left(\gamma \mathrm{B}_{1, \mathrm{H}}\right)$ was ramped over approximately $5 \mathrm{kHz}$, centered near the first sideband match at a $42 \mathrm{kHz}{ }^{1} \mathrm{H}$ field. Proton decoupling (CW) was employed during acquisition of all ${ }^{31} \mathrm{P}\left\{{ }^{1} \mathrm{H}\right\} \mathrm{CP} / \mathrm{MAS}$ spectra. The ${ }^{31} \mathrm{P}$ chemical shifts $\left(\delta_{\text {iso,P }}\right)$ were reported relative to external $85 \% \mathrm{H}_{3} \mathrm{PO}_{4}$ solution, using hydroxyapatite as a secondary reference set to $\delta_{\text {iso, } \mathrm{P}}=2.65 \mathrm{ppm}$.

\section{Statistical Data Analysis}

All chemical characterization data are expressed as means of duplicate measurements, with standard deviations showing the analytical precision. The results of analytical procedure blanks were incorporated in sample data processing. The relative abundance of various $\mathrm{P}$ forms is articulated as the percentage relative to the TP concentrations of the PL and biochar samples. Variations in speciation and bioavailability of $\mathrm{P}$ in PL and the derived biochars from different pyrolysis temperatures were statistically evaluated at the level of significance $\alpha=0.05$ following the analysis of variance (ANOVA) and the Fisher least significant difference (LSD) methods.

\section{RESULTS}

\section{Transformation of Organic P During Pyrolysis of PL to Biochar}

The PL contained $13.7 \mathrm{~g} \mathrm{~kg}^{-1} \mathrm{TP}$, of which $67.6 \%$ was IP and $32.4 \%$ belonged to OP. In the biochar products, the TP content was elevated to $22.7 \mathrm{~g} \mathrm{~kg}^{-1}$ for $\mathrm{C} 300$ and $30.5 \mathrm{~g} \mathrm{~kg}^{-1}$ for C600, increasing steadily as the pyrolysis temperature was raised (Table 1). The proportion of IP in the TP was also elevated to $87.0 \%$ for C300 and further to $99.7 \%$ for C450. When the pyrolysis temperature was increased to $500^{\circ} \mathrm{C}$ and above, the "nomial" proportion of IP (extractable by $1 \mathrm{M} \mathrm{HCl}$ ) decreased slightly from the peak value of nearly 100 to $96.6 \%$ in C500 and to $89.2 \%$ in C600 (Table 1). Correspondingly, the OP proportion decreased from $32.4 \%$ in raw PL to $13.0 \%$ in C300 and further to nearly null $(0.25 \%)$ in C450. As the pyrolysis temperature was elevated to $500^{\circ} \mathrm{C}$ and higher, the "nomial" OP proportion showed a slightly increasing trend in the resulting biochar products, reaching $10.8 \%$ in C600 (Table 1). The changes in IP and OP proportions between the biochars generated at 300$600^{\circ} \mathrm{C}$ with a $50^{\circ} \mathrm{C}$ interval were statistically significant, especially when the pyrolysis temperature was $\leq 450^{\circ} \mathrm{C}$ (Table 1).

\section{Redistribution of Labile P Fractions During Pyrolysis of PL to Biochar}

In raw PL, water-soluble P accounted for nearly half (49.5\%) of the TP, while the remaining half was shared by $\mathrm{NaHCO}_{3}$ extractable, $\mathrm{NaOH}$-extractable, $\mathrm{HCl}$-extractable, and residual $\mathrm{P}$ at
9.0, 5.5, 17.1, and 18.9\%, respectively (Figure 1). In PL-derived biochars, the portion of water-soluble $\mathrm{P}$ decreased radically to $11.7 \%$ of $\mathrm{TP}$ in $\mathrm{C} 300,8.7 \%$ in $\mathrm{C} 350,5.5 \%$ in $\mathrm{C} 400$, and further to $\sim 2.4 \%$ in biochars produced at $\geq 450^{\circ} \mathrm{C}$ pyrolysis temperatures. The proportion of $\mathrm{NaHCO}_{3}$-extractable $\mathrm{P}$, on the contrary, increased significantly to $20.4 \%$ in C300, fluctuated between 17.7 and $19.2 \%$ in C350, C400, C450, and C500. The proportion then descended to $10.8 \%$ in C550 and 9.7\% in C600. Similarly, the $\mathrm{NaOH}$-extractable P increased from $5.5 \%$ of TP in raw PL to the peak proportion of $13.2 \%$ (of TP) in C300 and then declined gradually to $9.2 \%$ in $\mathrm{C} 350,7.5 \%$ in $\mathrm{C} 400,4.2 \%$ in $\mathrm{C} 450,1.6 \%$ in $\mathrm{C} 500$, and to $<0.2 \%$ in biochars generated at $\geq 550^{\circ} \mathrm{C}$ pyrolysis temperatures (Figure 1). The sequentially $\mathrm{HCl}$-extractable $\mathrm{P}$ increased its proportion from $17.1 \%$ of TP in raw PL to $33.9 \%$ in $\mathrm{C} 300,52.2 \%$ in $\mathrm{C} 350$, and further to $60-$ $72 \%$ in biochars produced from $\geq 400^{\circ} \mathrm{C}$ pyrolysis. The residual $\mathrm{P}$ in $\mathrm{C} 300$ accounted for $20.8 \%$ of the TP, a percentage close to that of raw PL (18.9\%). The proportion decreased to $10.8 \%$ in C350 and reached the bottom level of 5.4\% in C450. Further elevation of the pyrolysis temperature caused back increases of the residual $\mathrm{P}$ proportion in the resulting biochar products, to 16.1\% in C600 (Figure 1). The residual P proportion profile is consistent with that of "nominally" OP (Table 1). In general, converting to biochar through pyrolysis significantly reduced the highly labile, highly leachable, and highly bioavailable (primarily water-soluble) $\mathrm{P}$ in PL.

Inorganic $\mathrm{P}\left(\mathrm{P}_{\mathrm{i}}\right.$, including orthophosphate- $\mathrm{P}\left(\mathrm{P}_{\mathrm{r}}\right)$ and polyphosphate- $\mathrm{P}\left(\mathrm{P}_{\mathrm{x}}\right)$ ) dominated the water-soluble $\mathrm{P}$ in $\mathrm{PL}$ and the derived biochars, accounting for $>89 \%$ of the total dissolved $\mathrm{P}\left(\mathrm{P}_{\mathrm{t}}\right)$ extractable by water (Table 2 ). In PL, for example, the water-soluble $\mathrm{P}$ consisted of $84.5 \% \mathrm{P}_{\mathrm{r}}, 4.5 \% \mathrm{P}_{\mathrm{x}}$, and $11.0 \% \mathrm{P}_{\mathrm{O}}$ (dissolved organic $\mathrm{P}$ ). The proportion of $\mathrm{P}_{\mathrm{O}}$ in water-soluble $\mathrm{P}$ from C300 decreased to $2.9 \%$, whereas the proportion of $\mathrm{P}_{\mathrm{X}}$ increased to $10.4 \%$ and $\mathrm{P}_{\mathrm{r}}$ to $86.7 \%\left(\mathrm{P}_{\mathrm{i}} 97.1 \%\right)$. The $\mathrm{P}_{\mathrm{o}}$ proportion

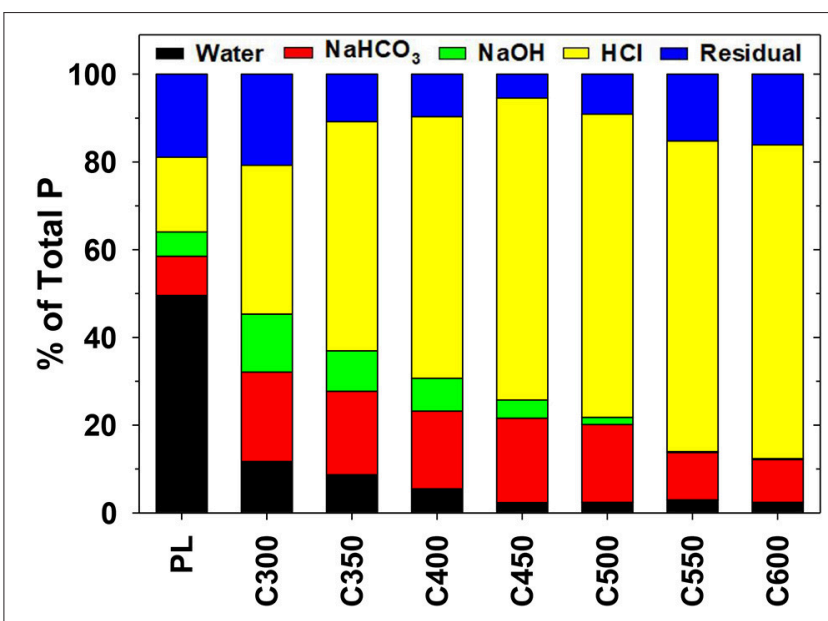

FIGURE 1 | Fractionation of phosphorus $(P)$ in poultry litter $(P L)$ and the derived biochars into water-extractable, $\mathrm{NaHCO}_{3}$-extractable, $\mathrm{NaOH}$-extractable, $\mathrm{HCl}$-extractable, and residual forms. Data are means of duplicate measurements. The coefficients of variation of the duplicate measurements are within $3 \%$. 
TABLE 2 | Composition of water-soluble, $\mathrm{NaHCO}_{3}$-extractable, and $\mathrm{NaOH}$-extractable phosphorus $(\mathrm{P})$ fractions in poultry litter (PL) and the derived biochars.

\begin{tabular}{|c|c|c|c|c|c|c|c|c|c|}
\hline & \multicolumn{3}{|c|}{ Water-soluble P } & \multicolumn{3}{|c|}{$\mathrm{NaHCO}_{3}$-extractable $\mathrm{P}$} & \multicolumn{3}{|c|}{$\mathrm{NaOH}$-extractable $\mathrm{P}$} \\
\hline & \multicolumn{3}{|c|}{$\%$ of water-soluble $P_{t}$} & \multicolumn{3}{|c|}{$\%$ of $\mathrm{NaHCO}_{3}$-extractable $\mathrm{P}_{\mathrm{t}}$} & \multicolumn{3}{|c|}{$\%$ of $\mathrm{NaOH}$-extractable $\mathrm{P}_{\mathrm{t}}$} \\
\hline PL & $84.5 \pm 0.66^{a}$ & $4.45 \pm 0.57^{\mathrm{c}, \mathrm{d}}$ & $11.0 \pm 1.23^{\mathrm{a}}$ & $75.2 \pm 0.32^{\mathrm{a}}$ & $6.82 \pm 1.10^{\mathrm{b}}$ & $17.9 \pm 0.77^{a}$ & $14.6 \pm 0.81^{a}$ & $19.8 \pm 0.38^{b}$ & $65.6 \pm 1.19^{\mathrm{a}}$ \\
\hline C300 & $86.7 \pm 0.11^{b}$ & $10.4 \pm 0.50^{\mathrm{a}}$ & $2.90 \pm 0.61^{b}$ & $86.7 \pm 0.41^{b}$ & $13.3 \pm 0.41^{a}$ & $0.00 \pm 0.00^{b}$ & $71.7 \pm 0.63^{b}$ & $24.4 \pm 0.38^{a}$ & $3.94 \pm 0.25^{b}$ \\
\hline $\mathrm{C} 450$ & $96.7 \pm 0.26^{\mathrm{e}}$ & $2.83 \pm 0.25^{\mathrm{d}, \mathrm{e}}$ & $0.51 \pm 0.01^{c}$ & $100 \pm 0.00^{e}$ & $0.00 \pm 0.00^{e}$ & $0.00 \pm 0.00^{b}$ & $100 \pm 0.00^{e}$ & $0.00 \pm 0.00^{e}$ & $0.00 \pm 0.00^{\mathrm{d}}$ \\
\hline C500 & $98.3 \pm 0.31^{f}$ & $1.69 \pm 0.31^{e}$ & $0.00 \pm 0.00^{d}$ & $100 \pm 0.00^{e}$ & $0.00 \pm 0.00^{e}$ & $0.00 \pm 0.00^{b}$ & $100 \pm 0.00^{e}$ & $0.00 \pm 0.00^{e}$ & $0.00 \pm 0.00^{\mathrm{d}}$ \\
\hline C550 & $100 \pm 0.009$ & $0.00 \pm 0.00^{f}$ & $0.00 \pm 0.00^{d}$ & $100 \pm 0.00^{e}$ & $0.00 \pm 0.00^{e}$ & $0.00 \pm 0.00^{b}$ & $100 \pm 0.00^{e}$ & $0.00 \pm 0.00^{e}$ & $0.00 \pm 0.00^{d}$ \\
\hline $\mathrm{C} 600$ & $100 \pm 0.009$ & $0.00 \pm 0.00^{f}$ & $0.00 \pm 0.00^{d}$ & $100 \pm 0.00^{e}$ & $0.00 \pm 0.00^{e}$ & $0.00 \pm 0.00^{b}$ & $100 \pm 0.00^{e}$ & $0.00 \pm 0.00^{\mathrm{e}}$ & $0.00 \pm 0.00^{\mathrm{d}}$ \\
\hline
\end{tabular}

Data are means \pm standard deviations of duplicate measurements. Superscript letters denote significance of difference between treatment levels. $P_{t}$, total dissolved phosphorus $(P)$; $P_{r}$, dissolved inorganic orthophosphate- $P$; $P_{x}$, dissolved inorganic polyphosphate- $P$; $P_{0}$, dissolved organic phosphorus.

of water-soluble $\mathrm{P}$ in biochar products decreased gradually as the production temperature was elevated in the range of $300-$ $600^{\circ} \mathrm{C}$; the $\mathrm{P}_{\mathrm{x}}$ proportion also decreased steadily; yet the $\mathrm{P}_{\mathrm{r}}$ proportion and the overall $P_{i}$ proportion increased accordingly. Organic P disappeared from the C500 water extract; only $\mathrm{P}_{\mathrm{r}}$ was present in water-soluble $\mathrm{P}$ of biochars produced at $\geq 550^{\circ} \mathrm{C}$ pyrolysis temperatures (Table 2). Sequential extraction of PL and the biochars by $\mathrm{NaHCO}_{3}$ after water showed the composition of $75.2 \% \mathrm{P}_{\mathrm{r}}, 6.9 \% \mathrm{P}_{\mathrm{x}}$, and $17.9 \% \mathrm{P}_{\mathrm{o}}$ in the extractable $\mathrm{P}$ from $\mathrm{PL}$ and $86.7 \% \mathrm{P}_{\mathrm{r}}, 13.3 \% \mathrm{P}_{\mathrm{x}}$, and $0.0 \% \mathrm{P}_{\mathrm{o}}$ in the extractable $\mathrm{P}$ from C300. Organic P completely disappeared from the sequential $\mathrm{NaHCO}_{3}$ extracts of biochars, while $\mathrm{P}_{\mathrm{x}}$ was only present in extracts from low-temperature biochars and decreased its proportion in products from higher temperature pyrolysis. In the sequential $\mathrm{NaHCO}_{3}$ extracts of $\mathrm{C} 450, \mathrm{P}_{\mathrm{x}}$ nulled and $\mathrm{P}_{\mathrm{r}}$ accounted for $100 \%$ of $P_{i}$ and $P_{t}$ (Table 2). The composition of $P$ in the sequential $\mathrm{NaOH}$ extracts demonstrated similar variation trends. The strongly alkaline $\mathrm{NaOH}$ solution is rather efficient for extracting organics from solid matrix. It was assumed that all remaining $\mathrm{P}_{\mathrm{o}}$ in the PL and biochars after the sequential $\mathrm{NaHCO}_{3}$ extraction would be recovered in the $\mathrm{NaOH}$ extracts. Consequently, $\mathrm{P}_{\mathrm{o}}$ was the principal form of $\mathrm{P}$ in the $\mathrm{NaOH}$ extracts from PL, accounting for $65.6 \%$ of the $\mathrm{P}_{t}$ (Table 2). In the $\mathrm{NaOH}$ extracts from $\mathrm{C} 300$, however, $\mathrm{P}_{\mathrm{o}}$ was merely $3.9 \%$ of the $\mathrm{P}_{\mathrm{t}}$, and proportion decreased to $0.0 \%$ in the extracts from C400. Meanwhile, $\mathrm{P}_{\mathrm{x}}$ decreased its proportion of $24.4 \%$ in the C300 extracts to $1.1 \%$ in the $\mathrm{C} 400$ extracts. In the $\mathrm{NaOH}$ extracts from C450, $\mathrm{P}_{\mathrm{r}}$ became the single form of dissolved P (Table 2).

Of the total extractable $\mathrm{P}$ from the four-stage sequential extraction (by water, $\mathrm{NaHCO}_{3}, \mathrm{NaOH}$, and $\mathrm{HCl}$ ), $\mathrm{P}_{\mathrm{r}}, \mathrm{P}_{\mathrm{x}}$, and $\mathrm{P}_{\mathrm{o}}$ accounted for $82.0,4.8$, and $13.2 \%$, respectively in PL. The composition changed to $89.9 \% \mathrm{P}_{\mathrm{r}}, 9.0 \% \mathrm{P}_{\mathrm{x}}$, and $1.1 \% \mathrm{P}_{\mathrm{o}}$ in C300 (Figure 2). In biochars produced at higher pyrolysis temperatures, both the extractable $\mathrm{P}_{\mathrm{o}}$ and $\mathrm{P}_{\mathrm{x}}$ demonstrated a steadily declining trend in proportion. The extractable $\mathrm{P}_{\mathrm{o}}$ and $\mathrm{P}_{\mathrm{x}}$ disappeared and $\mathrm{P}_{\mathrm{r}}$ was the only extractable $\mathrm{P}$ form in biochars prepared through $\geq 500^{\circ} \mathrm{C}$ pyrolysis (Figure 2). In consistent with Table 1, the results suggest transformation of $\mathrm{OP}$ to polyphosphate-P and further to orthophosphate-P during converting PL to biochar. The transformation was facilitated as the pyrolysis temperature was elevated.

\section{Potential Bioavailability of P in PL-Derived Biochars as Indicated by Extractability}

Water was able to extract $2.4-11.7 \%$ of TP in PL-derived biochars, the proportion decreasing readily to the minimum as the pyrolysis temperature was elevated in the range of $300^{\circ} \mathrm{C}$ to $450^{\circ} \mathrm{C}$ and above (Figure 3). In comparison, water extracted $49.5 \%$ of TP from raw PL under the same conditions. Clearly, conversion to biochar dramatically reduced the water solubility of $\mathrm{P}$ in PL. The Olsen solution $\left(0.5 \mathrm{M} \mathrm{NaHCO}_{3}, \mathrm{pH}\right.$ 8.5) performed slightly better than water in recovering P from PL and the derived biochars. The Olsen P accounted for $53.3 \%$ of TP in raw PL and $13.8-30.0 \%$ in biochars. Nevertheless, the pyrolysis temperature effect on the proportion of Olsen P in PL-derived biochar was not straightforward. For C300, the proportion was $21.6 \%$. The proportion increased to $30.0 \%$ for $\mathrm{C} 350$ yet then declined for biochars produced at higher pyrolysis temperatures, to $28.2 \%$ for C400 and $13.8 \%$ for C600 (Figure 3). The Bray-1 extractant $\left(0.025 \mathrm{M} \mathrm{HCl}\right.$ in $\left.0.03 \mathrm{M} \mathrm{NH}_{4} \mathrm{~F}\right)$ acted more efficiently than water and the Olsen extractant in recovering P from PL and the biochars. The solution was able to recover $73.3 \%$ of TP from raw PL and $17.0-57.8 \%$ of TP from the biochars. Furthermore, the proportion of Bray-1 extractable P in biochars decreased gradually as the pyrolysis temperature was elevated in the range of $300-600^{\circ} \mathrm{C}$ (Figure 3). Compared with the Bray- 1 extractant, the more corrosive Mehlich-3 solution $\left(0.2 \mathrm{M} \mathrm{CH}_{3} \mathrm{COOH}+\right.$ $0.013 \mathrm{M} \mathrm{HNO}_{3}+0.015 \mathrm{M} \mathrm{NH}_{4} \mathrm{~F}+0.001 \mathrm{M}$ EDTA $+0.25 \mathrm{M}$ $\mathrm{NH}_{4} \mathrm{NO}_{3}$ ) extracted $89.9 \%$ of TP from PL and $35.0-80.4 \%$ of TP from the biochars, among which C350 demonstrated the highest proportion (80.4\%) of Mehlich-3 P while C550 and C600 possessed the drastically lower (35-50\%) fractions (Figure 3). In contrast, the strongly acidic extractant $1 \mathrm{M} \mathrm{HCl}$ recovered $67.6 \%$ of TP from PL yet much higher proportions (87.0-99.8\%) from the biochars. All IP but little OP in soils and soil amendments was assumed extractable by $1 \mathrm{M} \mathrm{HCl}$. The high recovery of $\mathrm{P}$ by $\mathrm{HCl}$ extraction (Figure 3) implicated that inorganic phosphate 


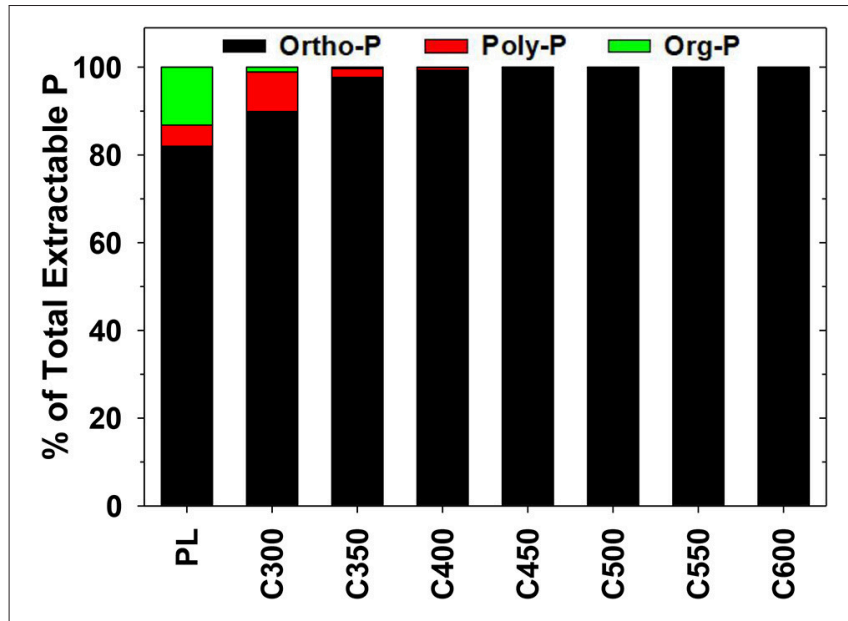

FIGURE 2 | Composition of total extractable phosphorus $(P)$ in poultry litter $(\mathrm{PL})$ and the derived biochars. Data are means of duplicate measurements. Superscript letters denote significance of difference between treatment levels.

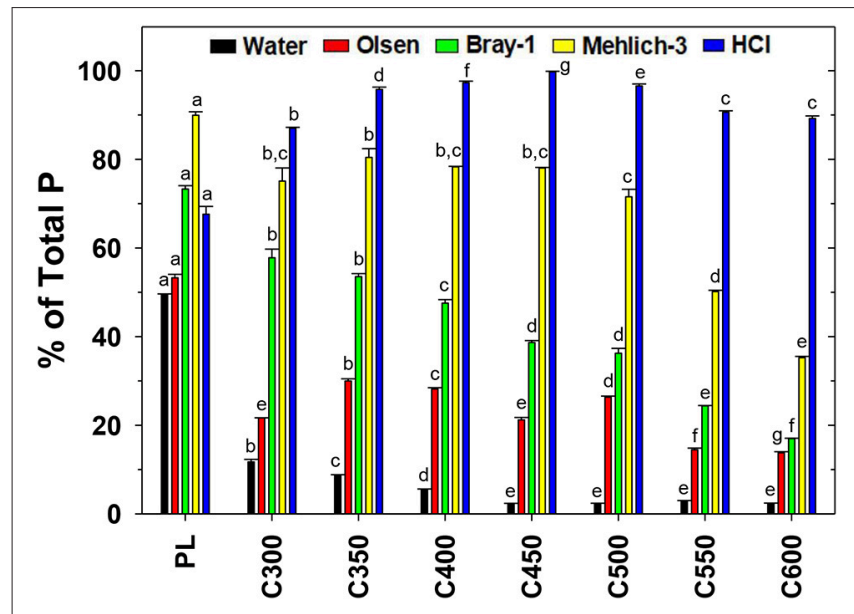

FIGURE 3 | Extractability (indicating leachability and potential bioavailability) of phosphorus $(\mathrm{P})$ in poultry litter $(\mathrm{PL})$ and the derived biochars by water, Olsen extractant, Bray-1 extractant, Mehlich-3 extractant, and $1 \mathrm{M} \mathrm{HCl}$. Data are means of duplicate measurements. Letters above bars denote significance of difference between treatment levels.

was the predominant $\mathrm{P}$ form in biochars. Overall, water, Bray1 , and $1 \mathrm{M} \mathrm{HCl}$ extracted significantly different proportions of $\mathrm{P}$ from $\mathrm{PL}$ and the biochars especially those generated at $\leq 450^{\circ} \mathrm{C}$, but the alkaline Olsen solution and the corrosive Mehlich-3 agent failed in this function (Figure 3).

\section{Spectroscopic Evidence of $P$ Species in PL-Derived Biochar}

The ${ }^{31} \mathrm{P}$ SP/MAS NMR spectra of the PL-derived biochars are illustrated in Figure 4. A broad peak at the chemical shift $\delta_{\mathrm{P}-31}=2.7 \mathrm{ppm}$ with full width at half maximum (FWHM) of 6.8 ppm was observed for $\mathrm{C} 300$. The chemical shift is fully consistent with that of hydroxyapatite $\left(\mathrm{Ca}_{10}\left(\mathrm{PO}_{4}\right)_{6}(\mathrm{OH})_{2}\right)$, but the FWHM is much broader than well-crystalline hydroxyapatite. This peak

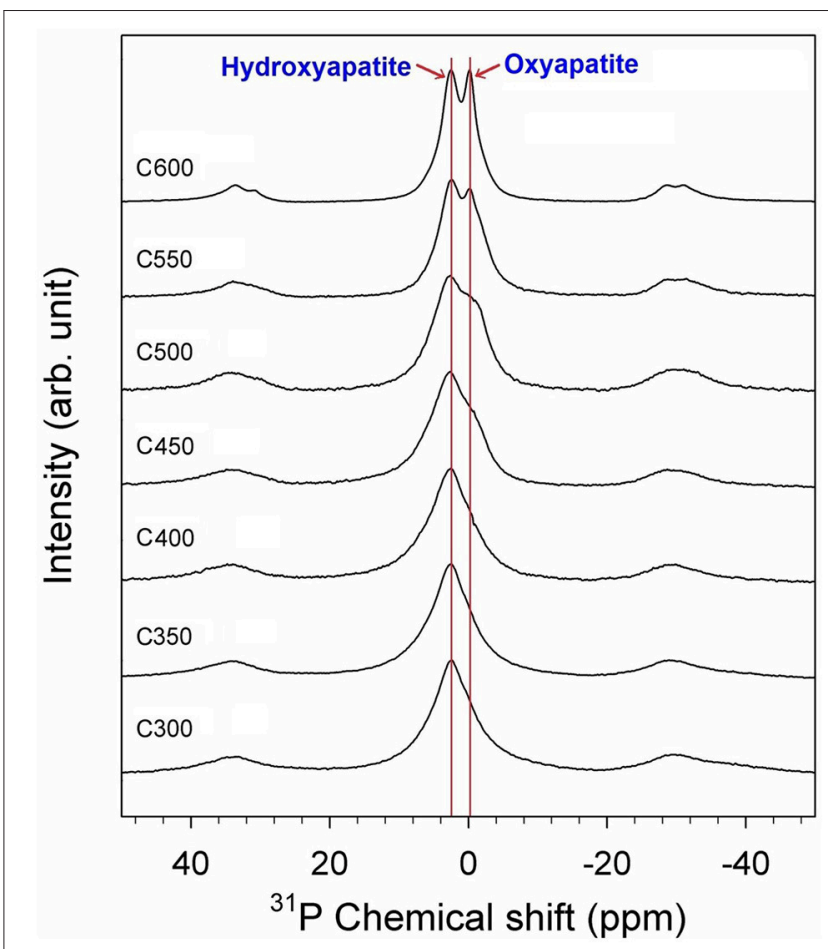

FIGURE 4 | ${ }^{31} \mathrm{P}$ SP/MAS NMR spectra of poultry litter-derived biochars from different pyrolysis temperatures. All spectra were collected at a spinning rate of $5 \mathrm{KHz}$ and pulse delay of $120 \mathrm{~s}$.

was therefore assigned to poorly crystalline hydroxyapatite (Jaeger et al., 2006; He et al., 2007; Vyalikh et al., 2017). The same peak was also observed for C350 and C400. As the pyrolysis temperature was elevated to $450^{\circ} \mathrm{C}$ an additional shoulder at $\delta_{\mathrm{P}-31}=-0.3 \mathrm{ppm}$ was observed for the biochar product, suggesting some poorly crystalline hydroxyapatite was transformed to a new species. This shoulder became more and more pronounced in biochars produced from higher temperature pyrolysis. Meanwhile, the major peak at $\delta_{\mathrm{P}-31}=2.7$ turned to be narrower with increasing the pyrolysis temperature, indicating facilitated crystallization of hydroxyapatite under higher temperature heating. At $600^{\circ} \mathrm{C}$, two well-separated NMR peaks at $\delta_{\mathrm{P}-31}=2.7$ and $-0.3 \mathrm{ppm}$ were identified (Figure 4). Assignment of the peak at $\delta_{\mathrm{P}-31}=2.7 \mathrm{ppm}$ to hydroxyapatite is further supported by the CP kinetics of C600 shown in the ${ }^{31} \mathrm{P}\left\{{ }^{1} \mathrm{H}\right\} \mathrm{CP} / \mathrm{MAS}$ NMR spectra (Figure 5), since only hydroxyapatite possesses such phosphate/proton environments that would yield stronger signal at a longer $\mathrm{CP}$ contact time (i.e., 5,000 $\mu$ s) than at a shorter CP contact time (e.g., 300 and $1,000 \mu \mathrm{s})$. The assignment of the shoulder peak at $\delta_{\mathrm{P}-31}=-0.3$ ppm was not straightforward. The compound from which the peak stemmed was most likely a dehydrated product of hydroxyapatite after heating. In the ${ }^{31} \mathrm{P}\left\{{ }^{1} \mathrm{H}\right\} \mathrm{CP} / \mathrm{MAS}$ spectra of $\mathrm{C} 600$, the peak at $\delta_{\mathrm{P}-31}=-0.3 \mathrm{ppm}$ shows no CP signals (Figure 5), implicating there are no protons associated with the $\mathrm{P}$ species. Though the peak occurred at a chemical shift rather close to that of $\beta$-tricalcium phosphate $\left(\mathrm{Ca}_{3}\left(\mathrm{PO}_{4}\right)_{2}\right)($ Sakka 


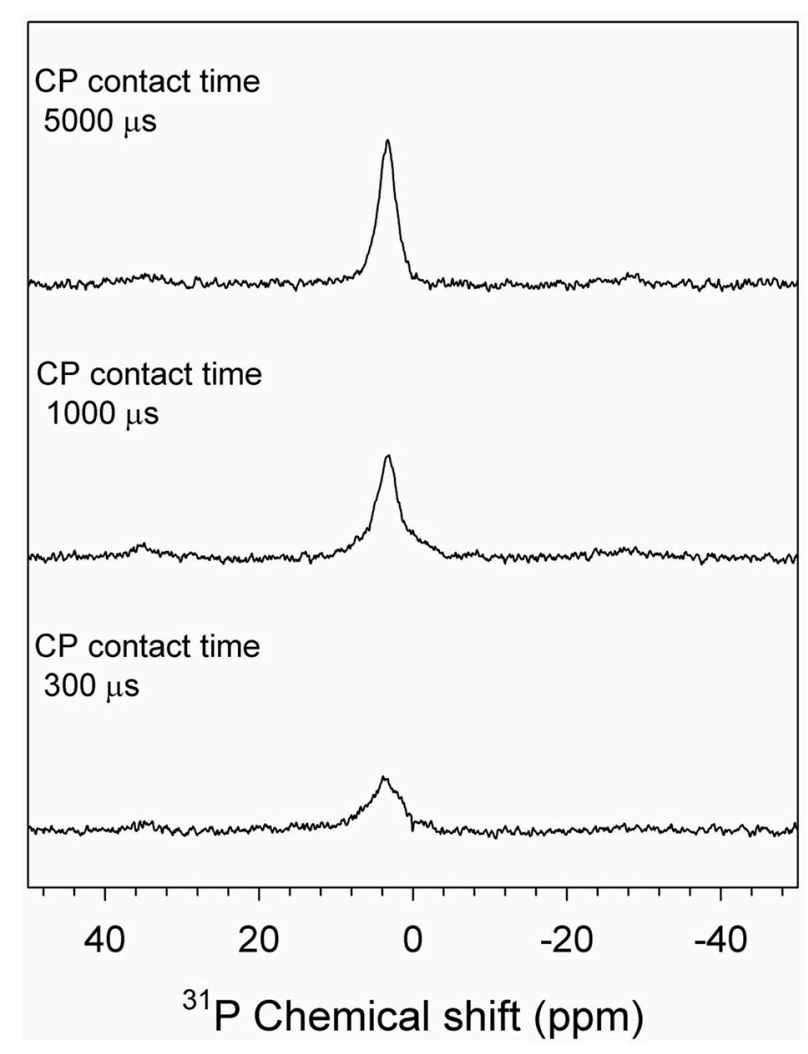

FIGURE $5 \mid{ }^{31} \mathrm{P}\left\{{ }^{1} \mathrm{H}\right\}$ CP/MAS spectra of the biochar $\mathrm{C} 600$ derived from poultry litter $(\mathrm{PL})$ through $600^{\circ} \mathrm{C}$ pyrolysis. The spectra were collected at varied $\mathrm{CP}$ contact times, spinning rate of $5 \mathrm{KHz}$, and a pulse delay of $2 \mathrm{~s}$.

et al., 2013), formation of tetracalcium phosphate $\left(\mathrm{Ca}_{4}\left(\mathrm{PO}_{4}\right)_{2} \mathrm{O}\right)$ and $\beta$-tricalcium phosphate $\left(\mathrm{Ca}_{3}\left(\mathrm{PO}_{4}\right)_{2}\right)$ from dehydrating hydroxyapatite required a much higher temperature (e.g., $>1000^{\circ} \mathrm{C}$ ) environment (Greenwood, 2014). At $600^{\circ} \mathrm{C}$, however, hydroxyapatite is ready to be dehydrated to form oxyapatite: $\mathrm{Ca}_{10}\left(\mathrm{PO}_{4}\right)_{6}(\mathrm{OH})_{2} \rightarrow \mathrm{Ca}_{10}\left(\mathrm{PO}_{4}\right)_{6} \mathrm{O}+\mathrm{H}_{2} \mathrm{O}$ (Greenwood, 2014). Therefore, the $\delta_{\mathrm{P}-31}=-0.3 \mathrm{ppm}$ peak was assigned to oxyapatite (Figure 4).

\section{DISCUSSION}

Pyrolysis of PL enriched the inherent non-volatile elements including $\mathrm{P}$ in biochar products. The enrichment became more prominent at higher pyrolysis temperatures in response to the decreasing biochar yield (Song and Guo, 2012). The enrichment factor of $\mathrm{P}$ (the ratio of TP content between biochar and $\mathrm{PL}$ ) for C300 was computed at 1.66. For C450 and C600, the factor increased to 1.94 and 2.23, respectively (Table 1). In addition to enrichment, speciation transformation of $\mathrm{P}$ was also evident. In $\mathrm{PL}$, both inorganic $\mathrm{P}$ species (e.g., dicalcium phosphate $\left(\mathrm{CaHPO}_{4}\right)$, amorphous tricalcium phosphate $\left(\mathrm{Ca}_{3}\left(\mathrm{PO}_{4}\right)_{2}\right.$, and octacalcium phosphate $\left.\left(\mathrm{Ca}_{8} \mathrm{H}_{2}\left(\mathrm{PO}_{4}\right)_{6} \cdot 5 \mathrm{H}_{2} \mathrm{O}\right)\right)$ and organic $\mathrm{P}$ species (e.g., phytates, phospholipids, and nucleic acids) are significantly present (Hunger et al., 2004; Turner and Leytem,
2004; Toor et al., 2005; He et al., 2008; Li et al., 2014). Most of the OP in PL was converted to inorganic forms during pyrolysis, as indicated by the drastic decreases in the proportion of OP yet abrupt increases in the proportion of IP in the derived biochars relative to raw PL (Table 1). Transformation of OP to metal/mineral-associated inorganic species was widely observed when converting sewage sludge, manures, and other solid biowastes to biochar through pyrolysis (Huang et al., 2017). Decomposition of OP was promoted by increasing the pyrolysis temperature. At $450^{\circ} \mathrm{C}$, nearly all $\mathrm{OP}$ in $\mathrm{PL}$ was converted to inorganic $\mathrm{P}$ species, with the product C450 showing an OP proportion close to 0\% (Table 1). The null presence of $\mathrm{OP}$ in biochars generated from $\geq 450^{\circ} \mathrm{C}$ pyrolysis was validated by the sequential extraction analyses, in which OP was barely recovered from these biochars by the extractants water, $\mathrm{NaHCO}_{3}$, and $\mathrm{NaOH}$ (Table 2; Figure 2). In Table 1, the unexpected increasing OP proportion for biochars produced at higher pyrolysis temperatures (C500, C550, and C600) was calculated based on the difference between TP and IP. As the pyrolysis temperature was elevated to $450^{\circ} \mathrm{C}$ and above, however, IP in the biochar products became more recalcitrant and less extractable by $1 \mathrm{M} \mathrm{HCl}$. This is supported by the sequential extraction results, showing increased proportions of residual $\mathrm{P}$ in biochars generated from $\geq 450^{\circ} \mathrm{C}$ pyrolysis (Figure 1). The "nominal" OP in C500, C550, and C600 (Table 1) was actually residual $\mathrm{P}$ (unextractable by $1 \mathrm{M}$ $\mathrm{HCl})$.

Indeed, transformation of OP to IP occurred during pyrolysis of PL to biochar. The transformation was initially to inorganic polyphosphates (i.e., condensed $\mathrm{P}$ forms including pyrophosphates, polyphosphates, and metaphosphates) and further to inorganic orthophosphates at higher pyrolysis temperature. Using solution ${ }^{31} \mathrm{P}$ NMR spectroscopic techniques, polyphosphates were detected in raw PL (Turner and Leytem, 2004; Dou et al., 2009), sewage sludge (Qian and Jiang, 2014; Huang and Tang, 2015), and other solid biowastes (Huang et al., 2017). Relative to raw PL, biochars generated at low pyrolysis temperature (e.g., C300) showed notably reduced proportion of extractable OP and correspondingly increased proportion of polyphosphate-P (Figure 2), suggesting transformation of OP to initially inorganic polyphosphates during pyrolysis. Elevating the pyrolysis temperature resulted in biochar products possessing decreased proportions of extractable polyphosphate-P yet increased proportions of orthophosphate$\mathrm{P}$ (Figure 2), implicating further conversion of polyphosphates to orthophospahtes. Raw PL is abundant in ash minerals, with the molar Ca/P ratio greater than 2.0 (Song and Guo, 2012). Seemingly, high temperature and sufficient metal ion supply facilitates transformation of polyphosphates to orthophosphates. Different forms of $\mathrm{P}$ vary in water solubility, mobility, and phytoavailability. Converting PL to biochar would substantially alter the environmental fate and transport of $\mathrm{P}$ following land application.

Conversion of PL to biochar greatly reduced the watersoluble $\mathrm{P}$ fraction (Figure 1), which is the most mobile and plant available $\mathrm{P}$ portion in PL. Runoff $\mathrm{P}$ losses are largely controlled by and directly correlated with the water-soluble P 
content of land-applied solid wastes (Shreve et al., 1995; Hart et al., 2004; White et al., 2010). Evidently, soil amendment with biochar instead of raw PL would minimize the highlyconcerned $\mathrm{P}$ runoff risks. The sequentially-used extractants water, $\mathrm{NaHCO}_{3}, \mathrm{NaOH}$, and $\mathrm{HCl}$ were designed to recover readily labile $\mathrm{P}$, generally labile $\mathrm{P}$ (adsorbed on crystalline mineral surfaces), moderately labile $\mathrm{P}$ (associated with carbonates and $\mathrm{Fe} / \mathrm{Al}$ oxides or in organic particulates), and low labile $\mathrm{P}$ (bound in Ca-minerals), respectively, in soils and solid residues (Hedley et al., 1982; Dou et al., 2000; He et al., 2006). Likely, the readily labile, water-soluble P in PL was transformed mainly to low labile and residual $\mathrm{P}$ (e.g., calcium phosphate minerals such as hydroxyapatite and oxyapatite) and marginally to generally/moderately labile $\mathrm{P}$ (e.g., amorphous $\mathrm{Ca}_{3}\left(\mathrm{PO}_{4}\right)_{2}$ surface precipitate on calcium carbonate and phosphate surface complexes on $\mathrm{Fe} / \mathrm{Al}$ oxides) (Figure 1). Phosphate surface precipitates and Fe/Al-oxide complexes were identified in PL using solid state MAS and CP-MAS ${ }^{31} \mathrm{P}$ NMR techniques (Hunger et al., 2004). Transformation of these two phases of phosphate to Ca-bound phosphates (e.g., hydroxyapatite) and further to residual P (e.g., oxyapatite) occurred possibly at higher temperature in the presence of available calcium (Figure 1). Overall, the labile portion of $\mathrm{P}$ (sequentially extractable by water, $\mathrm{NaHCO}_{3}$, and $\mathrm{NaOH}$; readily to moderately labile; and immediately to medium-term plant available) was significantly reduced during converting PL to biochar; and the reduction became greater as the pyrolysis temperature was elevated in the range of $300-600^{\circ} \mathrm{C}$. Similar $\mathrm{P}$ transformation trends were observed for pyrolysis of sewage sludge to biochar at different temperatures ranging from $400^{\circ} \mathrm{C}$ to $800^{\circ} \mathrm{C}$ (Qian and Jiang, 2014).

The labile portion of $\mathrm{P}$ in $\mathrm{PL}$ and the biochars was dominated by orthophosphates, with polyphosphates and organic $\mathrm{P}$ as minor forms (Table 2; Figure 2). For PL, all the three forms of $\mathrm{P}$ $\left(\mathrm{P}_{\mathrm{r}}, \mathrm{P}_{\mathrm{x}}\right.$, and $\left.\mathrm{P}_{\mathrm{o}}\right)$ were present in the water-soluble, $\mathrm{NaHCO}_{3}$ extractable, and $\mathrm{NaOH}$-extractable fractions. Organic $\mathrm{P}$ was the principal form of $\mathrm{P}$ in the $\mathrm{NaOH}$-extractable fraction, suggesting significant existence of $\mathrm{P}$-containing particulate organic matter in PL (Table 2). Due to the thermal decomposition of OP to IP, $\mathrm{P}_{\mathrm{o}}$ was detected only in the water-soluble and $\mathrm{NaOH}$-extractable fractions from the biochars generated at lower pyrolysis temperature $\left(\leq 450^{\circ} \mathrm{C}\right)$. Polyphosphates existed predominantly in the water-soluble $\mathrm{P}$ pool of biochars and fully disappeared in products from $\geq 550^{\circ} \mathrm{C}$ pyrolysis. Using coupled sequential extraction and solution ${ }^{31} \mathrm{P}$ NMR techniques, Qian and Jiang (2014) detected polyphosphates in sewage sludge and low pyrolysis temperature $\left(400-600^{\circ} \mathrm{C}\right)$ biochar products but not in high temperature $\left(800^{\circ} \mathrm{C}\right)$ biochars.

The bioavailability of $\mathrm{P}$ in soil is commonly estimated by batch extraction using a specific chemical extractant (Pierzynski, 2000). For example, the Olsen solution $\left(0.5 \mathrm{M} \mathrm{NaHCO}_{3}, \mathrm{pH}\right.$ 8.5) was introduced to extract phytoavailable $\mathrm{P}$ from neutral, alkaline, and calcareous soils by enhancing the dissolution of Ca-phosphates. The Bray-1 extractant was designed to recover water-soluble and adsorbed forms of $\mathrm{P}$ in $\mathrm{pH}<7.5$ soils. The Mehlich-3 extractant were developed to remove adsorbed and $\mathrm{Fe} / \mathrm{Al}$ oxides-complexed phosphates and other elements from acidic and neutral soils (Elrashidi, 2001). Lucero et al. (1998) found that both Bray-1 and Mehlich-3 extracts were effective to evaluate excess $\mathrm{P}$ in PL-fertilized soils. In the present study, the raw PL had a $\mathrm{pH}$ value of 7.1 and the biochars of 9.5-11.5, increasing with the pyrolysis temperature (Song and Guo, 2012). It is notable that all the chemical extractants recovered more $\mathrm{P}$ from PL and the biochars than water, and their effectiveness for extracting P from biochars followed the order: Olsen $<$ Bray- $1<$ Mehlich-3 < HCl (Figure 3). The Mehlich-3 solution was more efficient than $\mathrm{HCl}$ in extracting $\mathrm{P}$ from raw $\mathrm{PL}$, probably due to the abundance of OP (Table 1) that would be precipitated in $1 \mathrm{M}$ $\mathrm{HCl}$. The Bray-1 extractable $\mathrm{P}$ demonstrated a variation trend highly consistent with that of the labile $\mathrm{P}$ fraction (extractable by water, $\mathrm{NaHCO}_{3}$, and $\mathrm{NaOH}$ ) among the PL and the derivedbiochars (Figure 1), suggesting the solution is an appropriate extractant for evaluating the labile $\mathrm{P}$ content of PL-derived biochars. A large portion of $\mathrm{HCl}$-extractable, Ca-bound $\mathrm{P}$ is low labile yet long-term available to plants (Qian and Jiang, 2014) and therefore, Mehlich-3 was considered a proper solution for recovering overall bioavailable $\mathrm{P}$ from biochar. The Mehlich-3 extraction was able to reflect the changes in residual $\mathrm{P}$ fraction and general $\mathrm{P}$ recalcitrance of biochars produced at different pyrolysis temperatures (Figure 1). It is noteworthy that chemical extraction cannot reflect the interactions among soil, biochar, and plants tht influence the $\mathrm{P}$ bioavailabity of field applied biochar and therefore, the lability and bioavailability of P in PLderived biochars as evaluated by the present batch and sequential extraction methods need to be validated in soil-biochar-plant systems.

To date most phosphate compounds and organic $\mathrm{P}$ species in soil, solid biowastes, and biochars remain unknown due to the matrix complexity, $\mathrm{P}$ chemical diversity, and technology restriction. In addition to solid-state ${ }^{31} \mathrm{P}$ NMR techniques, other methods such as liquid ${ }^{31} \mathrm{P}$ NMR, X-ray absorption near edge structure (XANES) spectroscopy, Fourier transform infrared spectroscopy (FTIR), and X-ray diffraction (XRD) spectroscopy have been used to characterize $\mathrm{P}$ compounds in environmental samples (Toor et al., 2005; He et al., 2007; Dou et al., 2009; Li et al., 2014; Qian and Jiang, 2014; Huang and Tang, 2015; Huang et al., 2017). Identified P chemicals are limited to phytate, dicalcium phosphate, tricalcium phosphate, struvite $\left(\mathrm{NH}_{4} \mathrm{MgPO}_{4} \cdot 6 \mathrm{H}_{2} \mathrm{O}\right)$, hydroxyapatite, and broadly pyrophosphates (Hunger et al., 2008; Qian and Jiang, 2014; Huang and Tang, 2015; Huang et al., 2017). Hydroxyapatite does not exist in raw PL (Hunger et al., 2004). Instead, octacalcium phosphate, a precursor of hydroxyapatite, is present in PL (Hunger et al., 2008). The present ${ }^{31} \mathrm{P}$ NMR analysis indicates that hydroxyapatite was formed during pyrolysis of PL to biochar. Improved crystallization of hydroxyapatite occurred as the pyrolysis temperature was elevated. At $450^{\circ} \mathrm{C}$ and above, a portion of hydroxyapatite was dehydrated and transformed to possibly oxyapatite (Figure 4). Both hydroxyapatite and oxyapatite are water insoluble and belongs to the low labile $\mathrm{P}$ pool in sequential extraction. The speciation transformation supports the chemical extraction results that the solubility, lability, and bioavailability of $\mathrm{P}$ generally decreased in biochars produced from higher temperature pyrolysis. 


\section{CONCLUSIONS}

Nearly all $\mathrm{P}$ in the feedstock was recovered during pyrolytic conversion of PL to biochar. Relative to raw PL, the derived biochar was substantially P-enriched and might demonstrate a total $\mathrm{P}$ content doubling that of the original feedstock. During pyrolysis, OP in PL was decomposed to IP, initially to polyphosphates and subsequently to orthophosphates at higher temperature. Orthophosphate- $\mathrm{P}$ was the predominant form of $\mathrm{P}$ in PL-derived biochars. In the products manufactured at $\geq 450^{\circ} \mathrm{C}$ pyrolysis temperature, OP fully disappeared and polyphosphate$\mathrm{P}$ became barely detectable. Overall, pyrolysis transformed the $\mathrm{P}$ in raw PL to much less labile forms (e.g., hydroxyapatite and oxyapatite) in biochar. The lability of $\mathrm{P}$ in biochars decreased as the pyrolysis temperature increased in the range of 300$600^{\circ} \mathrm{C}$. Among the biochars generated at different temperatures, C450 possessed the smallest pool of residual $\mathrm{P}$, suggesting $450^{\circ} \mathrm{C}$ is the optimal temperature for converting PL to biochar with maximum $\mathrm{P}$ bioavailability. The Bray-1 extractant was an appropriate solution for recovering the immediately to mediumterm available $\mathrm{P}$ in biochar, while the Mehlich-3 solution was suitable for evaluating the overall $\mathrm{P}$ bioavailability of soilapplied biochar. The bioavailability of P in PL-derived biochars

\section{REFERENCES}

Bolan, N. S., Szogi, A. A., Chuasavathi, T., Seshadri, B., Rothrock, M. J., and Panneerselvam, P. (2010). Uses and management of poultry litter. Worlds. Poult. Sci. J. 66, 673-698. doi: 10.1017/S0043933910000656

Chan, K. Y., Van Zwieten, L., Meszaros, I., Downie, A., and Joseph, S. (2008). Using poultry litter biochars as soil amendments. Aust. J. Soil Res. 46, 437-444. doi: $10.1071 /$ SR08036

Coker, C. (2017). Poultry litter digestion. Biocycle 58, 50-51. Available online at: https://www.biocycle.net/2017/09/07/poultry-litter-digestion/

Dai, L., Li, H., Tan, F., Zhu, N., He, M., and Hu, G. (2016). Biochar: a potential route for recycling of phosphorus in agricultural residues. Glob. Change Biol. Bioenergy 8, 852-858. doi: 10.1111/gcbb.12365

de Jonge, V. N., Engelkes, M. M., and Bakker, J. F. (1993). Bio-availability of phosphorus in sediments of the western Dutch Wadden Sea. Hydrobiologia 253, 151-163. doi: 10.1007/BF00050735

Dou, Z., Toth, J. D., Galligan, D. T., Ramberg, C. F., and Ferguson, J. D. (2000). Laboratory procedures for characterizing manure phosphorus. J. Environ. Qual. 29, 508-514. doi: 10.2134/jeq2000.00472425002900020019x

Dou, Z., Toth, J. D., Wang, Y., Sharpley, A. N., Boyd, S. E., Chen, C. R., et al. (2009). Phosphorus speciation and sorption-desorption characteristics in heavily manured soils. Soil Sci. Soc. Am. J. 73, 93-101. doi: 10.2136/sssaj2007.0416

Elrashidi, M. A. (2001). Selection of an Appropriate Phosphorus Test for Soils. Lincoln, NE: USDA-NRCS Soil Survey Laboratory.

Greenwood, C. (2014). Physicochemical Modifications to Bone Mineral. dissertation/Ph.D. thesis, Cranfield University, Cranfield.

Guo, M., He, Z., and Uchimiya, S. M. (2016). "Introduction to biochar as an agricultural and environmental amendment," in Agricultural and Environmental Applications of Biochar: Advances and Barriers, ed M. Guo et al. (Madison, WI: Soil Science Society of America), 1-14.

Guo, M., Labreveux, M., and Song, W. (2009a). Nutrient release from bisulfateamended phytase-diet poultry litter under simulated weathering conditions. Waste Manage. 29, 2151-2159. doi: 10.1016/j.wasman.2009.02.012

Guo, M., Shen, Y., and He, Z. (2012). "Poultry litter-based biochar: preparation, characterization, and utilization," in Applied Research in Animal Manure Management: Challenges and Opportunities beyond the Adverse Environmental Impacts, ed Z. He (Hauppauge, NY: Nova Science Publishers), 171-202. needs to be further assessed in soil-biochar-plant systems. In addition to $\mathrm{P}$ lability and bioavailability, the remarkable $\mathrm{N}$ losses and potential stable $\mathrm{C}$ recovery should also be considered in selecting an optimal pyrolysis temperature for converting PL to biochar.

\section{AUTHOR CONTRIBUTIONS}

MG designed the experiments, synthesized the data, and drafted the paper. WL developed the research topic, participated in sample analysis, interpreted the spectroscopic results, and helped prepare the manuscript. XF carried out the spectroscopic analysis of the biochar samples, processed the spectral information, and reviewed the manuscript. WS conducted chemical characterization of the samples and reviewed the draft.

\section{ACKNOWLEDGMENTS}

This research was financially supported by National Natural Science Foundation of China (through Grant No. 41571130061) and the Delmarva Land Grant Institution Cooperative Seed Grant program.
Guo, M., Tongtavee, N., and Labreveux, M. (2009b). Nutrient dynamics of fieldweathered Delmarva poultry litter: implications for land application. Biol. Fertil. Soils 45, 829-838. doi: 10.1007/s00374-009-0397-4

Hart, M. R., Quin, B. F., and Nguyen, M. L. (2004). Phosphorus runoff from agricultural land and direct fertilizer effects: a review. J. Environ. Qual. 33, 1954-1972. doi: 10.2134/jeq2004.1954

He, Z., Honeycutt, C. W., Cade-Menun, B. J., Senwo, Z. N., and an d Tazisong, I. A. (2008). Phosphorus in poultry litter and soil: enzymatic and nuclear magnetic resonance characterization. Soil Sci. Soc. Am. J. 72, 1425-1433. doi: $10.2136 /$ sssaj2007.0407

He, Z., Honeycutt, C. W., Xing, B., McDowell, R. W., Pellechia, P. J., and Zhang, T. (2007). Solid-state Fourier transform infrared and 31P nuclear magnetic resonance spectral features of phosphate compounds. Soil Sci. 172, 501-515. doi: 10.1097/SS.0b013e318053dba0

He, Z., Toor, G. S., Honeycutt, C. W., and Sims, J. T. (2006). An enzymatic hydrolysis approach for characterizing labile phosphorus forms in dairy manure under mild assay conditions. Bioresour. Technol. 97, 1660-1668. doi: 10.1016/j.biortech.2005.07.021

Hedley, M. J., White, R. E., and Nye, P. H. (1982). Plant-induced changes in he rhizosphere of rape (Brassica napus var. Emerald) seedlings: III. Changes in L value, soil phosphate fractions and phosphatase activity. New Phytol. 91, 45-56. doi: 10.1111/j.1469-8137.1982.tb03291.x

Huang, R., Fang, C., Lu, X., Jiang, R., and Tang, Y. (2017). Transformation of phosphorus during (hydro)thermal treatments of solid biowastes: reaction mechanisms and implications for $\mathrm{P}$ reclamation and recycling. Environ. Sci. Technol. 51, 10284-10298. doi: 10.1021/acs.est.7b02011

Huang, R., and Tang, Y. (2015). Speciation dynamics of phosphorus during (hydro)thermal treatments of sewage sludge. Environ. Sci. Technol. 49, 14466-14474. doi: 10.1021/acs.est.5b04140

Hunger, S., Cho, H., Sims, J. T., and Sparks, D. L. (2004). Direct speciation of phosphorus in alum-amended poultry litter: solid-state 31P NMR investigation. Environ. Sci. Technol. 38, 674-681. doi: 10.1021/es034755s

Hunger, S., Sims, J. T., and Sparks, D. L. (2008). Evidence for struvite in poultry litter: effect of storage and drying. J. Environ. Qual. 37, 1617-1625. doi: 10.2134/jeq2007.0331

Jaeger, C., Maltsev, S., and Karrasch, A. (2006). Progress of structural elucidation of amorphous calcium phosphate (ACP) and hydroxyapatite (HAp): disorder 
and surfaces as seen by solid state NMR. Key Eng. Mater. 309-311, 69-72. doi: 10.4028/www.scientific.net/KEM.309-311.69

Li, G., Li, H., Leffelaar, P. A., Shen, J., and Zhang, F. (2014). Characterization of phosphorus in animal manures collected from three (dairy, swine, and broiler) farms in China. PLoS ONE 9:e102698. doi: 10.1371/journal.pone.0102698

Lucero, D. W., Martens, D. C., McKenna, J. R., and Starner, D. E. (1998). Comparison of Mehlich 3- and bray 1-extractable phosphorus levels in a Starr clay loam amended with poultry litter. Commun. Soil Sci. Plant Anal. 29, 1133-1142. doi: 10.1080/00103629809370014

Mierzwa-Hersztek, M., Gondek, K., and Baran, A. (2016). Effect of poultry litter biochar on soil enzymatic activity, ecotoxicity and plant growth. Agric,. Ecosyst. Environ. Appl. Soil Ecol. 105, 144-150. doi: 10.1016/j.apsoil.2016.04.006

Murphy, J., and Riley, H. P. (1962). A modified single solution method for the determination of phosphate in natural waters. Anal. Chim. Acta 27, 31-36. doi: 10.1016/S0003-2670(00)88444-5

NASA (2016). How farms affect the Chesapeake Bay's water: image of the day. National Aeronautics and Space Administration. Washington, DC. Available online at: https://earthobservatory.nasa.gov/IOTD/view.php?id=88523

Pierzynski, G. (2000). Methods of Phosphorus Analysis for Soils, Sediments, Residuals, and Waters. Southern Cooperative Series Bulletin. Raleigh, NC: North Carolina State University.

Qian, T., and Jiang, H. (2014). Migration of phosphorus in sewage sludge during different thermal treatment processes. ACS Sustainable Chem. Eng. 2, 1411-1419. doi: 10.1021/sc400476j

Revell, K. T., Maguire, R. O., and Agblevor, F. A. (2012). Influence of poultry litter biochar on soil properties and plant growth. Soil Sci. 177, 402-408. doi: $10.1097 /$ SS.0b013e3182564202

Sadras, V. O. (2005). The N:P stoichiometry of cereal, grain legume and oilseed crops. Field Crops Res. 95, 13-29. doi: 10.1016/j.fcr.2005.01.020

Sakka, S., Bouaziz, J., and Ayed, F. B. (2013). "Mechanical properties of biomaterials based on calcium phosphates and bioinert oxides for applications in biomedicine," in Advances in Biomaterials Science and Biomedical Applications, ed R. Pignatello (London, UK: InTech Open, Ltd), 23-50.
Shreve, B. R., Moore, P. A., Daniel, T. C., Edwards, D. R., and Miller, D. M. (1995). Reduction of phosphorus in runoff from field-applied poultry litter using chemical amendments. J. Environ. Qual. 24, 106-111. doi: 10.2134/jeq1995.00472425002400010015x

Song, W., and Guo, M. (2012). Quality variations of poultry litter biochars generated at different pyrolysis temperatures. J. Anal. Appl. Pyrolysis 94, 138-145. doi: 10.1016/j.jaap.2011.11.018

Toor, G. S., Peak, J. D., and Sims, J. T. (2005). Phosphorus speciation in broiler litter and turkey manure produced from modified diets. J. Environ. Qual. 34, 687-697. doi: 10.2134/jeq2005.0687

Turner, B. L., and Leytem, A. B. (2004). Phosphorus compounds in sequential extracts of animal manures: chemical speciation and novel fractionation procedure. Environ. Sci. Technol. 38, 6101-6108. doi: 10.1021/es0493042

Vyalikh, A., Elschner, C., Schulz, M. C., Mai, R., and Scheler, U. (2017). Early stages of biomineral formation-A solid-state NMR investigation of the mandibles of minipigs. Magnetochemistry 3:39. doi:10.3390/magnetochemistry3040039 doi: 10.3390/magnetochemistry3040039

Wang, Y., Lin, Y., Chiu, P., Imhoff, P. T., and Guo, M. (2015). Phosphorus release behaviors of poultry litter biochar as a soil amendment. Sci. Tot. Environ. 512-513, 454-463. doi: 10.1016/j.scitotenv.2015.01.093

White, J. W., Coale, F. J., Sims, J. T., and Shober, A. L. (2010). Phosphorus runoff from waste water treatment biosolids and poultry Litter applied to agricultural soils. J. Environ. Qual. 39, 314-323. doi: 10.2134/jeq2009.0106

Conflict of Interest Statement: The authors declare that the research was conducted in the absence of any commercial or financial relationships that could be construed as a potential conflict of interest.

Copyright (C) 2018 Li, Feng, Song and Guo. This is an open-access article distributed under the terms of the Creative Commons Attribution License (CC BY). The use, distribution or reproduction in other forums is permitted, provided the original author(s) and the copyright owner are credited and that the original publication in this journal is cited, in accordance with accepted academic practice. No use, distribution or reproduction is permitted which does not comply with these terms. 